\title{
Pertumbuhan Bibit F2 Jamur Tiram pada Berbagai Komposisi Media ( $F_{2}$ Oyster Mushroom Growth in Various Media Compositions)
}

\author{
Zarmiyeni \\ Program Studi Agroteknologi, Sekolah Tinggi Ilmu Pertanian Amuntai \\ Zarmiyenilg@yahoo.co.id
}

\begin{abstract}
ABSTRAK
Jamur tiram (Pleurotus ostreatus) merupakan salah satu jenis jamur kayu yang dimanfaatkan sebagai sayur dan makanan olahan. Dalam budidaya jamur tiram (Pleurotus ostreatus), bibit merupakan faktor penentu. Penelitian ini bertujuan untuk mendapatkan komposisi media terbaik pada pertumbuhan bibit $F_{2}$ jamur tiram (Pleurotus ostreatus). Penelitian yang dilaksanakan di Laboratorium STIPER Amuntai dari bulan April - Juni 2013, menggunakan Rancangan Acak Lengkap (RAL), dengan 5 perlakuan dan 4 ulangan. Sebagai perlakuan adalah komposisi media $(K)$ yaitu ( $\left.k_{1}\right) 80 \%$ jagung : $18 \%$ serbuk gergaji : $1 \% \mathrm{CaCO}_{3}: 1 \% \mathrm{CaSO}_{4},\left(k_{2}\right) 70 \%$ jagung: $28 \%$ serbuk gergaji : $1 \% \mathrm{CaCO}_{3}: 1 \% \mathrm{CaSO}_{4}$, ( $\left.k_{3}\right)$ 60\% jagung: $38 \%$ serbuk gergaji : 1\% $\left.\mathrm{CaCO}_{3}: 1 \% \mathrm{CaSO}_{4}, k_{4}\right) 50 \%$ jagung: $48 \%$ serbuk gergaji : 1\% $\left.\mathrm{CaCO}_{3}: 1 \% \mathrm{CaSO}_{4}, k_{5}\right)$ 40\% jagung: $58 \%$ serbuk gergaji : 1\% CaCO $\mathrm{CO}_{3}$ 1\% CaSO $\mathrm{C}_{4}$. Data pengamatan dianalisis dengan sidik ragam dan uji lanjut DMRT pada taraf nyata $5 \%$. Parameter yang diamati adalah pertumbuhan miselium secara horizontal dan vertikal. Hasil penelitian menunjukkan bahwa komposisi media (k2) 70\% jagung: 28\% serbuk gergaji : 1\% $\mathrm{CaCO}_{3}: 1 \% \mathrm{CaSO}_{4} \mathrm{memberikan}$ hasil terbaik untuk pertumbuhan bibit $F_{2}$.
\end{abstract}

Kata kunci: Jamur tiram, bibit, komposisi, media, pertumbuhan.

\section{ABSTRACT}

Oyster mushroom (Pleurotus ostreatus) is one type of wood mushroom that is used as a vegetable and processed food. In the cultivation of oyster mushrooms (Pleurotus ostreatus), seeds are a determining factor. This study aims to obtain the best media composition in the growth of oyster mushroom $F_{2}$ seedlings (Pleurotus ostreatus). The research conducted at the Amuntai STIPER Laboratory from April to June 2013, using a Completely Randomized Design (CRD), with 5 treatments and 4 replications. As a treatment, the composition of media $(\mathrm{K})$ is $\left(k_{1}\right)$ 80\% corn: $18 \%$ sawdust: $1 \% \mathrm{CaCO}_{3}: 1 \% \mathrm{CaSO}_{4},\left(k_{2}\right)$ 70\% corn: $28 \%$ sawdust: $1 \% \mathrm{CaCO}_{3}: 1 \% \mathrm{CaSO}_{4},\left(k_{3}\right) 60 \%$ corn: $38 \%$ sawdust: $1 \% \mathrm{CaCO}_{3}: 1 \% \mathrm{CaSO}_{4}$, (k) $50 \%$ corn: $48 \%$ sawdust: $1 \% \mathrm{CaCO}_{3}: 1 \% \mathrm{CaSO}_{4},\left(k_{5}\right)$ 40\% corn: $58 \%$ sawdust : $1 \% \mathrm{CaCO}_{3}: 1 \%$ $\mathrm{CaSO}_{4}$. Observation data were analyzed by variance and DMRT follow-up at 5\% level. The parameters observed were the growth of mycelium horizontally and vertically. The results showed that media composition ( $\left.k_{2}\right) 70 \%$ corn: $28 \%$ sawdust: $1 \% \mathrm{CaCO}_{3}: 1 \% \mathrm{CaSO}_{4}$ gave the best results for $\mathrm{F}_{2}$ seedling growth.

Keywords: Oyster mushrooms, seeds, composition, media, growth.

\section{PENDAHULUAN}

Jamur tiram (Pleurotus ostreatus) merupakan salah satu jenis jamur kayu yang dapat dijumpai hampir sepanjang tahun dan hidup di permukaan batang pohon yang sudah melapuk di lokasi yang sangat lembab serta terlindung dari cahaya matahari (Wiardani, 2010). Jamur tiram dapat dijadikan sebagai sayuran dan makanan olahan. Kaya akan protein, mengandung asam amino yang lengkap, vitamin $B_{1}, B_{2}$ dan beberapa garam mineral
(Soenanto, 2000). Menurut Tim Karya Tani Mandiri (2010) jamur tiram (Pleurotus ostreatus) berkhasiat menurunkan darah tinggi, diabetes, kelebihan kolesterol, anemia, meningkatkan daya tahan tubuh terhadap serangan polio dan influenza.

Berdasarkan data dari Badan Pusat Statistik Kalimantan Selatan (2012), belum ada masyarakat yang membudidayakan jamur tiram (Pleurotus ostreatus) di Kabupaten Hulu Sungai Utara namun dilihat dari produksi jamur Kalimantan Selatan adalah $27.403 \mathrm{~kg} / \mathrm{m} 3$ dan luas 
lahan sekitar $1.815 \mathrm{~m} 3$ dengan rata-rata produksi sebanyak 15,10 kg/m3.

Kabupaten Hulu Sungai Utara sangat berpotensi dalam pengembangan budidaya jamur tiram (Pleurotus ostreatus). Hal ini disebabkan media tumbuh untuk jamur ini sangat mudah didapat diantaranya seperti serbuk gergaji dan dedak. Disamping itu jamur atau dikenal dengan nama "kulat" sudah tidak asing bagi masyarakat Hulu Sungai Utara. Namun dalam pengembangan budidayanya terkendala dalam pengadaan bibit jamur tiram (Pleurotus ostreatus) sebagai bahan inokulan awal.

Dalam pembuatan bibit jamur jamur tiram (Pleurotus ostreatus) ada beberapa tahapan yang harus dilakukan. Tahap pertama adalah pengambilan kultur murni dari jamur $\left(\mathrm{F}_{0}\right)$ dilanjutkan dengan penanaman biakan $\mathrm{F}_{0}$ ke media tanam yang disebut pembiakan tahap satu (bibit $F_{1}$ ). Dari bibit $F_{1}$ kita harus menurunkannya lagi ke dalam media tanam yang nantinya disebut bibit $F_{2}$. Tahap terakhir adalah penanaman bibit $F_{2}$ ke dalam baglog (pembudidayaan bibit $\mathrm{F}_{3}$ ) (Wiardani, 2010).

Dalam kegiatan budidaya jamur tiram, pembuatan bibit merupakan salah satu kegiatan sub budidaya yang menduduki posisi penting (Rachmat, 2000 dalam Hamdiyati, 2010). Bibit jamur merupakan faktor yang menentukan seperti halnya bibit untuk tanaman lainnya, karena dari bibit yang unggul akan menghasilkan tubuh buah yang berkualitas tinggi dan memungkinkan dapat beradaptasi terhadap lingkungan yang lebih luas. Untuk menghasilkan bibit yang berkualitas maka diperlukan media yang optimal artinya dapat menyediakan nutrisi yang diperlukan jamur untuk pertumbuhan dan perkembangannya disamping kondisi lingkungan yang optimal.

Menurut Soenanto (2000), jamur tiram (Pleurotus ostreatus) umumnya dapat tumbuh di berbagai media, baik yang secara alami (batang pohon berkayu) maupun media lain, seperti serbuk gergaji. Bahan baku media serbuk gergaji itu sendiri masih ditambah formula lain. Menurut Parjimo \& Andoko (2007), formula tersebut khususnya untuk pembibitan $\mathrm{F}_{2}$ adalah jagung sebanyak $8 \%$, serbuk gergaji sebanyak $40 \%$, kapur $\left(\mathrm{CaCO}_{3}\right)$ sebanyak $11 \%$ dan gips $\left(\mathrm{CaSO}_{4}\right)$ sebanyak 5\%. Namun menurut Djarijah \& Djarijah (2001), ada formula lain lagi seperti limbah sekam (80-95\%), dedak halus (5-20\%), $\mathrm{CaCO}_{3}(1-2 \%)$.

Penelitian ini bertujuan untuk mendapatkan komposisi media terbaik pada pertumbuhan bibit $F_{2}$ jamur tiram (Pleurotus ostreatus).

\section{METODE PENELITIAN}

Penelitian yang dilaksanakan di Laboratorium STIPER Amuntai dari bulan April - Juni 2013, menggunakan bahan inokulan $F_{1}$ jamur tiram putih dari Asosiasi Pembudidayaan Jamur Indonesia (APJI) Jakarta, jagung, serbuk gergaji berasal dari jenis kayu Jagor (Anthocephalus cadamba) dan Kapur Naga (Calophyllum macrocarpum), kapur $\left(\mathrm{CaCO}_{3}\right),\left(\mathrm{CaSO}_{4}\right)$, kapas, alkohol $70 \%$ dan spritus, Sedangkan alat berupa plastik polipropilen, karet gelang, pinset, ayakan, ember, panci, alat sterilisasi, lampu Bunsen, thermometer dan timbangan analitik,

Penelitian ini menggunakan Rancangan Acak Lengkap (RAL) satu faktor dengan 5 taraf perlakuan dan 4 ulangan. Data dianalisis menggunakan sidik ragam dengan uji lanjut Uji Duncan's Multiple Range Test pada taraf nyata 5\%. Sebagai perlakuan adalah komposisi media tanam (K) yaitu :

$$
\begin{aligned}
& \mathrm{k}_{1}=80 \% \text { jagung : } 18 \% \text { serbuk gergaji }: 1 \% \mathrm{CaCO}_{3}: 1 \% \mathrm{CaSO}_{4} \\
& \mathrm{k}_{2}=70 \% \text { jagung: } 28 \% \text { serbuk gergaji }: 1 \% \mathrm{CaCO}_{3}: 1 \% \mathrm{CaSO}_{4} \\
& \mathrm{k}_{3}=60 \% \text { jagung: } 38 \% \text { serbuk gergaji }: 1 \% \mathrm{CaCO}_{3}: 1 \% \mathrm{CaSO}_{4} \\
& \mathrm{k}_{4}=50 \% \text { jagung: } 48 \% \text { serbuk gergaji }: 1 \% \mathrm{CaCO}_{3}: 1 \% \mathrm{CaSO}_{4} \\
& \mathrm{k}_{5}=40 \% \text { jagung: } 58 \% \text { serbuk gergaji }: 1 \% \mathrm{CaCO}_{3}: 1 \% \mathrm{CaSO}_{4}
\end{aligned}
$$


Media tanam dibuat dengan cara mencampur biji jagung yang telah direbus dengan serbuk kayu, kapur, gips diaduk hingga rata lalu ditambahkan air hingga $60 \%$, hingga air tidak menetes apabila digenggam. Media dimasukan ke dalam kantong plastik ukuran 15 x $30 \mathrm{~cm}$ sebanyak $200 \mathrm{~g}$, kemudian ujung plastik diikat dengan karet gelang. Media ini disterilisasi pada suhu 1210C dan tekanan 1,5 psi selama 30 menit.

Media yang telah steril diidinginkan lalu diinokulasi dengan bibit $\mathrm{F}_{1}$ sebanyak 50 g. Selanjutnya media yang sudah diinokulasi $F_{1}$ ujungnya diberi kapas dan diikat. Inkubasi atau proses menumbuhkan miselium jamur dilakukan dengan cara menyimpan media perlakuan biakan $\mathrm{F} 2$ pada rak-rak dengan suhu kamar dalamm kondisi gelap. Selama kurang lebih 2-4 minggu media akan ditumbuhi miselium. Parameter yang diamati adalah penyebaran miselium secara dan vertikal dan horizontal yang diamati 7, 14, 21 dan 28 hari setelah inokulasi (HSI).

\section{HASIL DAN PEMBAHASAN}

\section{Hasil}

\section{Penyebaran Miselium Secara Vertikal}

Berdasarkan hasil analisis ragam, perlakuan komposisi media tanam berpengaruh sangat nyata terhadap penyebaran miselium secara vertikal pada umur 7 dan 14 HSI namun tidak berpengaruh pada umur 21 dan 28 HSI. Rerata Penyebaran miselium secara vertikal disajikan pada Tabel 1.

Tabel 2. Pengaruh komposisi media tanam terhadap rerata penyebaran miselium secara vertikal umur 7, 14, 21 dan 28 HSI.

\begin{tabular}{|c|c|c|c|c|}
\hline \multirow{2}{*}{ Perlakuan } & \multicolumn{4}{|c|}{ Rerata penyebaran miselium secara vertikal $(\mathrm{cm})$} \\
\cline { 2 - 5 } & $7 \mathrm{HSI}$ & $14 \mathrm{HSI}$ & $21 \mathrm{HSI}$ & $28 \mathrm{HSI}$ \\
\hline $\mathrm{k} 1$ & $3,4^{\mathrm{ab}}$ & $4,13^{\mathrm{ab}}$ & 0 & 0 \\
$\mathrm{k} 2$ & $5,1^{\mathrm{b}}$ & $9,52^{\mathrm{c}}$ & 10,84 & 11,91 \\
$\mathrm{k} 3$ & $4,01^{\mathrm{b}}$ & $6,74^{\mathrm{bc}}$ & 7,55 & 8,56 \\
k4 & $3,28^{\mathrm{a}}$ & $5,30^{\mathrm{ab}}$ & 6,32 & 6,69 \\
$\mathrm{k} 5$ & $2,39^{\mathrm{a}}$ & $3,73^{\mathrm{a}}$ & 4,18 & 4,62 \\
\hline
\end{tabular}

Keterangan : Nilai rerata yang diikuti huruf superscript yang sama pada kolom yang sama tidak berbeda berdasarkan uji DMRT pada taraf nyata $5 \%$.

Dari Tabel 1 terlihat bahwa perlakuan $\mathrm{k}_{2}$ menghasilkan miselium terpanjang pada setiap pengamatan. Pada umur 7 HSI penyebaran miselium yang terpanjang secara vertikal terdapat pada perlakuan $\mathrm{k}_{2}$ yaitu $5,1 \mathrm{~cm}$ yang berbeda dengan perlakuan $\mathrm{k}_{4}$ dan $\mathrm{k}_{5}$ tetapi tidak berbeda dengan perlakuan $\mathrm{k}_{1}$ dan $\mathrm{k}_{3}$. Pada umur 14 HSI penyebaran miselium yang terpanjang secara vertikal terdapat pada perlakuan $\mathrm{k}_{2}$ yaitu $9,52 \mathrm{~cm}$ yang berbeda dengan perlakuan $\mathrm{k}_{1}$, $\mathrm{k}_{4}$ dan $\mathrm{k}_{5}$ tetapi tidak berbeda dengan perlakuan $\mathrm{k}_{3}$. Pada umur 21 dan 28 HSI tidak ada pengaruh komposisi media terhadap penyebaran miselium secara vertikal.

\section{Penyebaran Miselium Secara Horizontal}

Berdasarkan hasil analisis ragam menunjukkan bahwa perlakuan komposisi media tanam berpengaruh sangat nyata terhadap penyebaran miselium secara horizontal pada umur 7 dan 14 HSI namun tidak berpengaruh pada umur 21 dan 28 HSI. Rerata Penyebaran miselium secara horizontal disajikan pada Tabel 2.

Tabel 2. Pengaruh komposisi media tanam terhadap rerata penyebaran miselium secara 
horizontal umur 7, 14, 21 dan 28 HSI.

\begin{tabular}{|c|c|c|c|c|}
\hline \multirow{2}{*}{ Perlakuan } & \multicolumn{4}{|c|}{ Rerata penyebaran miselium secara horizontal $(\mathrm{cm})$} \\
\cline { 2 - 5 } & $7 \mathrm{HSI}$ & $14 \mathrm{HSI}$ & $21 \mathrm{HSI}$ & $28 \mathrm{HSI}$ \\
\hline k1 & $6,01^{\mathrm{c}}$ & $6,93^{\mathrm{a}}$ & 0 & 0 \\
k2 & $6,07^{\mathrm{c}}$ & $12,1^{\mathrm{b}}$ & 13,06 & 13,92 \\
k3 & $3,70^{\mathrm{b}}$ & $7,62^{\mathrm{a}}$ & 8,43 & 11,41 \\
k4 & $2,72^{\mathrm{b}}$ & $6,31^{\mathrm{a}}$ & 7,58 & 8,26 \\
k5 & $2,35^{\mathrm{a}}$ & $5,1^{\mathrm{a}}$ & 6,65 & 7,46 \\
\hline
\end{tabular}

Keterangan : Nilai rerata yang diikuti huruf superscript yang sama pada kolom yang sama tidak berbeda berdasarkan uji DMRT pada taraf nyata $5 \%$.

Dari Tabel 2 terlihat bahwa komposisi media tanam menghasilkan adanya penyebaran miselium secara horizontal yang signifikan pada umur 7 dan 14 HSI. Pada umur 7 HSI penyebaran miselium yang terpanjang secara horizontal terdapat pada perlakuan $\mathrm{k}_{2}$ yaitu $6,07 \mathrm{~cm}$ yang berbeda dengan perlakuan k3, k4 dan $\mathrm{k}_{5}$ tetapi tidak berbeda dengan perlakuan $\mathrm{k}_{1}$. Pada umur 14 HSI menghasilkan penyebaran miselium yang terpanjang secara horizontal terdapat pada perlakuan $\mathrm{k}_{2}$ yaitu $12,1 \mathrm{~cm}$ yang berbeda dengan perlakuan $\mathrm{k}_{1}, \mathrm{k}_{3}, \mathrm{k}_{4}$ dan $\mathrm{k}_{5}$.

\section{Pembahasan}

Perlakuan komposisi media tanam mempengaruhi penyebaran miselium secara horizontal dan vertikal pada umur 7 dan 14 HSI. Penyebaran miselium semakin meningkat seiring dengan makin banyaknya jagung yang diberikan pada masing-masing media perlakuan, namun penambahan jagung lebih banyak lagi menurunkan penyebaran miselium. Menurut Djarijah \& Djarijah (2001) menyebutkan bahwa jamur tiram membutuhkan protein, vitamin (B1, B3, B5 dan B7) serta mineral (N, P, K, $\mathrm{Ca}, \mathrm{Mg}$ dan lain-lain).

Selain jagung, bibit $F_{2}$ jamur tiram juga membutuhkan selulosa dan lignin untuk proses pertumbuhannya. Selulosa tersebut didapat dari serbuk gergaji yang diberikan pada masing-masing perlakuan. Walaupun miselium jamur tiram $F_{2}$ membutuhkan selulosa untuk pertumbuhannya, namun ketersediaan serbuk gergaji yang semakin banyak diberikan pada media perlakuan akan semakin memperlambat proses dekomposisi sehingga pertumbuhannya pun melambat. Hal tersebut mempengaruhi semua perlakuan yang ada.

Perlakuan penyebaran miselium pada media secara horizontal berpengaruh sangat nyata pada umur 7 dan 14 HSI lebih cepat pertumbuhannya pada bagian permukaan atas media (horizontal) apabila dibandingkan dengan perlakuan penyebaran miselium pada media secara vertikal, hal ini kemungkinan disebabkan oleh faktor gravitasi. Tidak berpengaruhnya perlakuan pada variabel penyebaran miselium secara vertikal dan horizontal pada pengamatan 21 dan 28 HSI karena meningkatnya kadar air pada media pembibitan. Kadar air yang meningkat tersebut disebabkan oleh bahan media pembibitan yaitu biji jagung yang membusuk sehingga menghambat pertumbuhan miselium. Lebih lanjut DEPTAN (2004) menjelaskan bahwa media yang membusuk akan menghambat pertumbuhan miselium dan akhirnya menyebabkan kematian bagi miselium tersebut.

Selain itu, pada umur 21 dan 28 HSI juga terkontaminasi jamur lain. Jamur parasit dan saprofit yang mengganggu pertumbuhan dan kehidupan jamur tiram dapat dideteksi dari warna spora dan miselium jamur. Menurut Djarijah \& Djarijah (2001), jamur parasit dan saprofit ini juga memanfaatkan nutrisi media tumbuh sebagai sumber makanannya. Tim Karya Tani Mandiri (2010) juga menjelaskan bahwa jamur yang tumbuh di media pembibitan tersebut adalah 
Trichoderma spp. dan Penicillium spp. yang ditandai dengan timbulnya bintikbintik atau noda hijau (Trichoderma spp.) dan coklat/merah tua (Penicillium spp.).

Perlakuan komposisi k2 (70\% jagung : $28 \%$ serbuk gergaji : $1 \% \mathrm{CaCO}_{3}: 1 \%$ $\left.\mathrm{CaSO}_{4}\right)$ merupakan perlakuan terbaik, dimana pada komposisi inilah yang paling mencukupi kebutuhan miselium jamur tiram $\mathrm{F}_{2}$ dalam pertumbuhannya. Pada media yang memiliki banyak biji jagung justru akan memberi dampak terhadap peningkatan kadar air pada media (perlakuan $\mathrm{k}_{1}$ ). Selain itu, perlakuan yang memiliki lebih banyak serbuk gergajinya akan mengakibatkan lambatnya pertumbuhan miselium jamur tiram $\mathrm{F}_{2}$. Hal tersebut disebabkan serbuk gergaji yang digunakan belum terdekomposisi secara sempurna. Selain itu serbuk gergaji yang digunakan tidak homogen (campuran serbuk kayu jabon dan kapur naga) sehingga proses pengomposan dan pertumbuhan miselium terhambat karena berbedanya tekstur dari kedua serbuk gergaji sebagaimana disebutkan oleh Satriyanto (2010), dalam pembuatan media hendaknya menggunakan jenis kayu yang homogen atau tidak bercampur. Ini berpengaruh dalam lamanya waktu pengomposan dan juga tentunya perkembangan miselium.

Dilihat dari segi waktu penyebaran miselium merata pada media didapatkan komposisi media pembibitan terbaik yaitu ketika umur bibit jamur tiram $\mathrm{F}_{2}$ mencapai $28 \mathrm{HSI}$ hampir memenuhi media pembibitan pada perlakuan $\mathrm{k}_{2}$. Dibandingkan dengan waktu penyebaran miselium merata pada beberapa literatur, perlakuan k2 terlihat lebih baik. Menurut Widayastuti \& Tjokrokusumo (2008) menyatakan bahwa bibit jamur tiram dapat dipanen ketika sudah berumur 45-60 HSI atau ketika media sudah berwarna putih merata. Pendapat ini sesuai dengan pendapat GNC (2008) bahwa bibit jamur tiram dapat dipanen ketika media sudah berwarna putih merata atau ketika bibit sudah berumur 45-60 HSI (hari setelah inokulasi).

\section{KESIMPULAN}

Perlakuan komposisi $\mathrm{k}_{2}$ (70\% jagung : $28 \%$ serbuk gergaji : $1 \% \mathrm{CaCO}_{3}: 1 \%$ $\left.\mathrm{CaSO}_{4}\right)$ merupakan komposisi media yang efektif untuk pertumbuhan bibit F2 jamur tiram (Pleurotus ostreatus).

\section{DAFTAR PUSTAKA}

Badan Pusat Statistik Provinsi Kalimantan Selatan. 2012. Kalimantan Selatan Dalam Angka 2012. Badan Pusat Statistik Kalimantan Selatan : Banjarmasin.

Departemen Pertanian. 2004. Budidaya Jamur (Pleurotus Sp). Departemen Pertanian. Jakarta.

Djarijah, N.M \& Djarijah, A. S. 2001. Budidaya Jamur Tiram (Pembibitan, Pemeliharaan dan Pengendalian Hama-Penyakit). Penerbit Kanisius. Yogyakarta.

GNC. 2008. Budidaya Jamur Tiram (Pleurotus ostreatus). bbpplembang.info. Diakses tanggal 2 Desember 2012.

Hamdiyati, Y. 2010. Serbuk gergaji kayu dan biji jagung sebagai media dalam pembuatan bibit induk. http://file.upi.edu/Direktori/FPMIPA/ JUR._PEN. _BIOLOGI. Diakses tanggal 25 Juni 2013.

Parjimo \& Andoko, A. 2007. Budidaya Jamur (Jamur Kuping, Jamur Tiram dan Jamur Merang). Agromedia Pustaka. Solo.

Satriyanto, F. 2010. Kegagalan dalam Budidaya Jamur Tiram. Jamursekolahdolan.blogspot.com. Diakses tanggal 08 Juni 2013.

Soenanto, H. 2000. Jamur Tiram Budidaya dan Peluang Usaha. Aneka Ilmu. Semarang.

Tim Karya Tani Mandiri. 2010. Pedoman Budidaya Jamur. CV. Nuansa Aulia. Bandung. 
Wiardani, I . 2010. Budidaya Jamur Konsumsi (Menangguk Untung dari Budidaya Jamur Tiram dan Jamur Kuping). Lily Publisher. Yogyakarta.

Widyastuti, N \& Tjokrokusumo, D. 2008. Aspek lingkungan sebagai penentu keberhasilan budidaya jamur tiram (Pleurotus sp). Pusat Teknologi Bioindustri Badan Pengkajian dan Penerapan Teknologi. http://ejurnal.bppt.go.id. Diakses tanggal 21 November 2012. 